\title{
WHO ARE THE STAKEHOLDERS MENTIONED IN CASES OF PRODUCT-SERVICE SYSTEM (PSS) DESIGN?
}

\author{
Fernandes, Sânia da Costa; Martins, Luiza Diegues; Rozenfeld, Henrique \\ University of São Paulo
}

\begin{abstract}
Product-service systems (PSS) are solutions that integrate product and services in order to fulfill the customers' needs by means of greater value in use. Multiple stakeholders should be involved in the design process for the development of a successful PSS value proposition. However, it is not clear who could be the potential stakeholders of a PSS. The aims of this study are to consolidate the stakeholders cited in PSS case studies and to reveal the terms used to refer to "stakeholder" in PSS literature. A systematic literature review was carried out, and an inductive content analysis procedure was applied. A total of 28 stakeholders were listed from the selected studies, whose PSS cases were classified as useoriented or result-oriented services. Multiple terminologies are used to refer to stakeholders. This study contributes for showing the potential stakeholders that can be involved and engaged in the PSS design and operation. Also, it indicates the terms from which they can be addressed in the PSS literature.
\end{abstract}

Keywords: Product-Service Systems (PSS), Early design phases, Collaborative design

\author{
Contact: \\ Fernandes, Sânia da Costa \\ University of São Paulo \\ Production Engineering \\ Brazil \\ saniafernandes@usp.br
}




\section{INTRODUCTION}

Manufacturing companies are challenged to innovate in different aspects of their business to increase the value added through the offerings. Product-Service System (PSS) emerges as a business strategy that claims to fulfill the customer needs when providing integrated solutions of products and services (Baines et al., 2007; Boehm and Thomas, 2013). Servitization is the transformation process that supports business innovation towards PSS (Baines et al., 2009).

Servitization and PSS design require the development of a new business model, which is guided by the value proposition (Laurischkat and Viertelhausen, 2017). A successful value proposition relies on the organizations' ability to meet the interests of stakeholders, providing benefits to a large number of them (Gilles and Christine, 2016). The decision-making process when designing PSS value propositions should involve different stakeholders, since decisions may impact the entire PSS lifecycle. The PSS business model should, therefore, create, deliver and capture value considering the coexistence of multiple stakeholders.

Identifying, in the initial stages of design, the potential value that a PSS can offer for stakeholders is challenging (Panarotto, Wall and Larsson, 2017). Having a multiple stakeholder approach is a key role for organizations. Especially, when developing a PSS value proposition, companies should make explicit and systematic the consideration of stakeholders (Morioka, Evans and Carvalho, 2016). It is needed to understand and evaluate the needs of the complex network of stakeholders since the preliminary stages of development to solve the design trade-offs (Bertoni et al., 2016). This implies identifying the key stakeholders of the system and recognizing their knowledge and context (Frow and Payne, 2011). Stakeholders should be identified prior to developing the alternatives of solutions as PSS "draws upon a lot of internal and external resources" (Medini and Boucher, 2016).

However, the multiple stakeholders approach is poorly addressed in the literature of PSS design and implementation (Medini and Boucher, 2016). Some studies only present theoretical frameworks or methods for supporting the stakeholder activity design (e.g., Krucken and Meroni (2006) and Kim et al. (2011)). It is not clear who are the main stakeholders of a PSS. Companies are not fully aware of which individuals or groups should be considered as stakeholders (Frow and Payne, 2011). A starting point to solve this issue in order to support companies when designing PSS value propositions is to clarify who could be the potential stakeholders within the system and those to be involved in it (Frow and Payne, 2011). Otherwise, some stakeholders could be neglected in the design process.

This study aims to consolidate who are the different stakeholders of PSS by listing those cited in PSS case studies. Having a list of stakeholders provide a fundamental practical basis for supporting researchers and practitioners in identifying the different individuals or groups that should be involved and integrated into a specific PSS design process. Also, this paper aims to reveal which terms stand as equivalent to the "stakeholder" term in PSS and servitization literature.

This paper is structured as follows. Section 2 presents the research background. Section 3 describes the research methodology. The results and discussions are presented in section 4. Lastly, the final remarks are presented in the last section (section 5).

\section{RESEARCH BACKGROUND}

Frameworks can support manufacturing companies in the servitization journey and in the PSS design (Rozenfeld, Rosa and Fernandes, 2018). However, paths to servitize a company is still demanding (Baines et al., 2017) and servitization and PSS themes are continually being relevant and attracting interests from different fields and industries (Annarelli, Battistella and Nonino, 2016).

PSS typologies have been created for providing ideal types of PSS based on the variations of the offerings (Park, Geum and Lee, 2012). The most applicable typology for characterizing PSS was developed by Tukker (2004). The author proposed three main categories of PSS based on the ratio between product and service in the offering. According to Tukker (2004), PSS is product-oriented service when it involves the traditional sales of a product with additional services being offered to guarantee the functionality of the product. The second category is the use-oriented service, in which the PSS provider delivers the use or availability of a product. Last, the PSS can be result-oriented service when the provider and customer mutually agree on a solution to be delivered (Tukker, 2004). PSS can be associated with higher complexity of offerings and value for stakeholders, who are defined as groups or individuals that can impact or be impacted by the PSS (Yip, Phaal and Probert, 2013). They can be internal (e.g., research \& development department) or external (e.g., customer, dealers, 
and further firm environment) from the PSS provider, and they can be evaluated by a variety of attributes, such as power, interest, influence, and legitimacy (Yip, Phaal and Probert, 2013).

For supporting both design and operation of the PSS solution, stakeholders of a PSS should be identified prior to the value proposition design (Medini and Boucher, 2016). Stakeholders that act in the use and end-of-life phases should be involved since the early stages of the PSS design process. Cavalieri; Pezzotta (2012) argue that the PSS success relies on the company's ability in covering the entire system's lifecycle to create a scenario that satisfies the needs and interests of all stakeholders. A multiple stakeholder approach offers an interesting perspective for PSS success (Evans, Partidário and Lambert, 2007; Velamuri, Neyer and Möslein, 2011). This fact indicates the importance of including different points of view of the most important stakeholders in the definition of PSS solutions.

\section{RESEARCH METHODOLOGY}

In order to consolidate the stakeholders mentioned in cases of PSS design, a systematic literature review (SLR) was carried out. This strategy was selected since the SLR follows "a scientific and transparent process" (Annarelli, Battistella and Nonino, 2016) through an exhaustive search of papers. The existing body of knowledge in case studies is explored to uncover who are the stakeholders of the PSS and which synonyms are employed to refer to them in a general way. This allows building a solid foundation for researchers and practitioners in the PSS field. The literature review process proposed by Levy and Ellis (2006) was applied, which is described in the following subsections.

\subsection{Data collection}

First, the research scope and search strategy were defined. The unit of analysis was scholarly or peerreviewed studies in English within the scope of case studies in PSS and servitization-related domain. The goal was to integrate previous PSS case studies to list the stakeholders cited in them and, also, the terms that stand as equivalent to "stakeholder" in this literature. The search string was proposed containing a set of keywords derived from previous literature reviews. The keywords were systematically tested through preliminary searches, and they are related to the major scholarly communities in the field of PSS and servitization, as presented in Rabetino et al. (2018). The search string contains primary search keywords and supplementary search keywords. The primary search terms were "complex products and systems", "custom* solutions", "from products to services", "integrated product-services", "integrated solutions", "product service syste*", "product/service syste*", "product-service offerings", "product-service syste*", "service infusion", "service science", "service transition", "servicification", "servicisation", "servicization,"“serviti*", or "solution business models" (Rabetino et al., 2018). The supplementary search terms were "case stud*" or "case research*", and "stakeholder*". The electronic database selected to perform the systematic literature review was Scopus, as it embeds a wide range of subjects, journals and conferences in the management science domain (Tukker, 2015).

For the evaluation and selection of the relevant papers, two main criteria were defined. The papers must: (1) to describe real cases of PSS or servitization, not being a conceptual study (i.e., not only indicating the strategy of case study for further application of frameworks); (2) to present examples of stakeholders. A preliminary set of 94 papers were retrieved from the database. Based on these criteria, three steps in a screening process were employed (Figure 1). The first reading filter comprised the reading of the title, abstract and keywords. In the second reading filter, potential papers were assessed by reading the introduction and conclusion. Finally, the resulting papers were read completely and additional papers were included through a backward and a forward searches (Webster and Watson, 2002). The final dataset includes 20 papers, whose year of publication ranges from 2006 to early 2017.

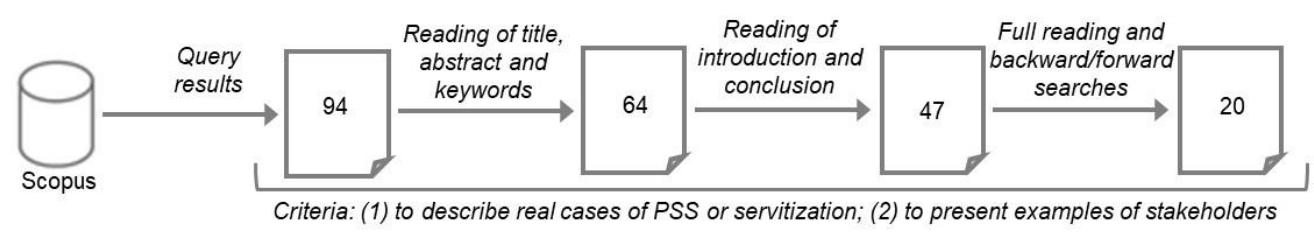

Figure 1. Outputs of the screening process of the SLR based on the selection criteria Elaborated by the authors 


\subsection{Data analysis}

For each paper in the final dataset, an inductive content analysis procedure was applied based on Elo and Kyngäs (2008). The analysis consisted of three major rounds of analysis with different focuses. The first round focused on understanding the PSS case descriptions and identifying in which category of the typology proposed by Tukker (2004) they fit. Tukker's (2004) classification is the most cited in the literature and it is considered as the most appropriate to characterize PSS (Beuren, Ferreira and Miguel, 2013). The second round of analysis focused on consolidating the stakeholders cited in the PSS case study by documenting them. Finally, the analysis focused on identifying which are the different terms used as a synonym of "stakeholder" or those equivalent words employed to refer to the term "stakeholder" by the authors of the cases in PSS literature.

\section{RESULTS AND DISCUSSIONS}

\subsection{Classification of PSS cases}

The final publications obtained from the systematic literature review process are consolidated in Table 1. Most of the studies have been published recently. Since the introduction of the term "productservice system" in literature, a greater number of theoretical studies have been developed when compared to practical researches. Recent studies have focused on trying to describe real cases of PSS.

Table 1. Dataset of publications (elaborated by the authors)

\begin{tabular}{|c|c|c|}
\hline Reference & PSS case & PSS categorization \\
\hline (Överholm, 2017) & Solar panels as an energy service & Result-oriented \\
\hline (Benedetti et al., 2016) & $\begin{array}{l}\text { Energy consumption monitoring and control } \\
\text { combined with energy meters }\end{array}$ & Result-oriented \\
\hline (Ferreira et al., 2016) & $\begin{array}{l}\text { Aircraft along with a range of services between } \\
\text { FAB (manufacturer) and JETFAST (customer) }\end{array}$ & Result-oriented \\
\hline $\begin{array}{l}\text { (Gilles and Christine, } \\
\text { 2016) }\end{array}$ & $\begin{array}{c}\text { "Shower head" as a service developed by } \\
\text { ECOBEL }\end{array}$ & Result-oriented \\
\hline $\begin{array}{l}\text { (Hannon, Foxon and } \\
\text { Gale, 2015) }\end{array}$ & $\begin{array}{c}\text { Energy service provision by Energy Service } \\
\text { Company (ESCo) }\end{array}$ & Result-oriented \\
\hline $\begin{array}{l}\text { (Hollauer, } \\
\text { Venkataraman and } \\
\text { Omer, 2015) }\end{array}$ & Electric bicycles sharing & Use-oriented \\
\hline $\begin{array}{l}\text { (Lucile, Alan and } \\
\text { Daniel, 2015) }\end{array}$ & Pneumatic energy delivery system & Result-oriented \\
\hline $\begin{array}{l}\text { (Peruzzini, Marilungo } \\
\text { and Germani, 2015) }\end{array}$ & Washer Dryer addressed to connectivity & Result-oriented \\
\hline $\begin{array}{l}\text { (Rivas-Hermann, Köhler } \\
\text { and Scheepens, 2015) }\end{array}$ & $\begin{array}{l}\text { PSS of ballast water treatment systems in the } \\
\text { shipping retrofit industry }\end{array}$ & Result-oriented \\
\hline (Zhang et al., 2015) & Bike sharing & Use-oriented \\
\hline (Ziout and Azab, 2015) & PSS for spreading and leveling grains & Result-oriented \\
\hline $\begin{array}{l}\text { (Zolnowski, Weiß and } \\
\text { Böhmann, 2014) }\end{array}$ & Mobile payment service in the retail industry & Result-oriented \\
\hline $\begin{array}{l}\text { (Yip, Phaal and Probert, } \\
\text { 2013) }\end{array}$ & $\begin{array}{l}\text { Health ICT (information and communication } \\
\text { technology) }\end{array}$ & Result-oriented \\
\hline (Panarotto et al., 2013) & PSS Car dashboard PSS & Result-oriented \\
\hline (Vasantha et al., 2013) & Lease of a laser machine & Use-oriented \\
\hline (Kim et al., 2012) & Urban umbrella rental & Use-oriented \\
\hline $\begin{array}{l}\text { (Zonghu, Dandan and } \\
\text { Jian, 2012) }\end{array}$ & Diesel engine PSS & Result-oriented \\
\hline (Bergema et al., 2011) & $\begin{array}{l}\text { Better Place, a case of electric vehicle } \\
\text { networks and services }\end{array}$ & Result-oriented \\
\hline $\begin{array}{l}\text { (Tan, Mcaloone and } \\
\text { Gall, 2007) }\end{array}$ & $\begin{array}{c}\text { Sustainable office workspace performance by } \\
\text { Steelcase }\end{array}$ & Use-oriented \\
\hline (Williams, 2006) & Micro-factory retailing (MRF) & Use-oriented \\
\hline
\end{tabular}


The case studies cover different industrial sectors, particularly automotive (04 papers) and energy (04 papers) sectors. It may indicate that companies are advancing in areas such as mobility solutions, heating solutions, electric vehicle sharing, etc.

Based on Tukker's (2004) typology, those case studies can be classified into two main PSS types: useoriented services (06 papers) and result-oriented services (14 papers). Although the product-oriented service is the least complex PSS type to be introduced by companies, since it does not imply major changes in business model or in the technological system (Tukker, 2004), none study was categorized in this type. The most recurrent PSS category is result-oriented services. Those findings may indicate that the involvement of internal and external stakeholders from the company is even more relevant in PSS business models where, in principle, the value chain should be changed radically. This means that, compared with the product-oriented services, the success of a use-oriented or result-oriented services rely heavily on stakeholder agreements to operate more effectively.

Mainly in result-oriented service, the value creation and capture are more complex for provisioning service access, inducing a need to integrate multiple know-how from different stakeholders. Proper involvement and cooperation between internal and external stakeholders become strategic to support the design and implementation of an integrated solution. As result-oriented service is considerably different from the traditional business models (based on product sales), this category of PSS can be associated with higher complexity of the offerings and value. Thus, the stakeholder network to create and deliver such offerings become more crucial.

\subsection{Stakeholders of PSS}

Most of the articles, which were excluded during the literature review process, are restricted to theoretical research or case studies that cite the term "stakeholders" in a generic and broader way, without detailing who they are and what are their roles in the design and operation of a PSS.

The final studies differ on how the stakeholders are presented, especially with regard to the information details. There are papers that presented the stakeholders of the PSS in a superficial manner, demanding the recognition of them as the reading was performed. In its turn, some studies focused on identifying a heterogeneous set of stakeholders involved in the PSS design or operation, or even those that are impacted by the decisions. Gilles and Christine (2016), for example, investigated the stakeholders on the value system of the ECOBEL's PSS regarding the aspects of security, traceability and maintenance, sustainability and economic issue. Yip, Phaal and Probert (2013) grouped different stakeholders engaged in the new health ICT PSS based on different degrees of proximity of them to the operations of the PSS (business environment, system, product, and service delivery). Panarotto et al. (2013) defined a value network comprising several stakeholders involved in the development of a car dashboard when dealing with PSS' design. Kim et al. (2012) proposed a PSS design process, in which one major phase is the stakeholder activity design. The last authors identified the stakeholders related to the umbrella rental and their requirements via life-cycle analysis.

The PSS stakeholders that were identified from the literature review are presented in Table 2. A total of 28 stakeholders were retrieved from the selected studies. Groups or individuals mentioned in the PSS cases were compiled in the standard groups shown in Table 2. For example, technicians (Lucile, Alan and Daniel, 2015) and consultants (Tan, Mcaloone and Gall, 2007) were classified in the group "installation and service partner"; the automotive energy supply corporation (Bergema et al., 2011) was categorized as "supplier"; and, the individuals responsible for the station of an umbrella provision machine (Kim et al., 2012) was allocated in the "provider for checkout and terminals" group.

The most recurrent stakeholders, i.e. that have the highest citation frequency among all references, are customer, manufacturer, installation and service partner, and supplier. This indicates "patterns" of stakeholders considered in the PSS literature, i.e., they are regarded as normative examples to be considered when designing a PSS. However, manufacturer, installation and service partner, and supplier are linked to the provision sphere of the solutions which is separated from the customer sphere. Usually, those stakeholders are not approached in a joint sphere needed for co-creating value propositions. The PSS should not be designed considering only the perspective of the groups involved in the provision of the solution. It requires the consideration of customers as active actors instead of passive audiences. More than that, the demands of other stakeholders should be aligned by addressing co-creation opportunities that expand the customer-provider context. This indicates that even those stakeholders are the most recurrent, others listed in Table 2 should also be engaged in the PSS design. 


\begin{tabular}{|c|c|c|c|c|c|c|c|c|c|c|c|c|c|c|c|c|c|c|}
\hline & \multicolumn{18}{|c|}{ References } \\
\hline Stakeholders & A & B & $\mathrm{C}$ & $\mathrm{D} E$ & $\mathrm{E} \mid \mathrm{F}$ & $\mathrm{G}$ & $\mathrm{H}$ & $\begin{array}{ll}\mathrm{I} & \mathrm{J}\end{array}$ & K & $\mathrm{L}$ & $\mathrm{M} I$ & $\mathrm{~N}$ & $\mathrm{O}$ & $\mathrm{P}$ & Q & $\mathrm{R}$ & $\mathrm{S}$ & $\mathrm{T}$ \\
\hline Customer / Consumer & $\bullet$ & • & $\bullet$ & - $\bullet$ & • $\bullet$ & $\bullet$ & $\bullet$ & & • & • & • & • & • & & - & & $\bullet$ & \\
\hline Manufacturer & $\bullet$ & $\bullet$ & $\bullet$ & & & & & • $\bullet$ & • & & • & • & • & • & • & & & • \\
\hline $\begin{array}{l}\text { Installation and service } \\
\text { partner }\end{array}$ & $\bullet$ & $\bullet$ & $\bullet$ & & & $\bullet$ & & $\bullet \cdot \bullet$ & & & • & & • & $\bullet$ & & & $\cdot$ & $\bullet$ \\
\hline Supplier & & $\bullet$ & & & $\bullet$ & $\bullet$ & & • & & & $\bullet$ & $\bullet$ & • & & & • & $\bullet$ & $\bullet$ \\
\hline User & & & & & • & & & $\bullet$ & & & - & $\bullet$ & & $\bullet$ & & & & \\
\hline Financial partner & • & & & & - & & & • $\bullet$ & & & & & & & - & & & \\
\hline Government & $\bullet$ & & & & • $\bullet$ & & & & & & & & & & $\bullet$ & $\bullet$ & & \\
\hline $\begin{array}{l}\text { Industry interest } \\
\text { group/authority/standard } \\
\text { /domain experts }\end{array}$ & & & & & & & & & & & $\bullet$ & & & & & • & & • \\
\hline Insurer & $\bullet$ & & & & & & & • & & & & $\bullet$ & & & & & & \\
\hline Society & & $\bullet$ & & $\bullet$ & & & & & $\bullet$ & & & & & & $\bullet$ & & & \\
\hline $\begin{array}{l}\text { Provider for checkout } \\
\text { and terminals }\end{array}$ & & & & & • & & & & & • & & & & • & & • & & \\
\hline Local provider & & $\bullet$ & & & $\bullet$ & & - & • & & & • & & & & & & & \\
\hline Competitors & & & & & & & & $\bullet$ & & & & & & & $\bullet$ & & & \\
\hline Shipping company & & & & & & & & & $\bullet$ & & & & & & & & & \\
\hline $\begin{array}{l}\text { Regulators/non- } \\
\text { commercial relationship }\end{array}$ & $\bullet$ & & & & $\bullet$ & & & & & & & & & & & & & \\
\hline Environment & & $\bullet$ & & & & & & & & & & & & & & & & \\
\hline After service firm & & & • & & & & & & & & & & & & & & & \\
\hline Entertainment firm & & & • & & & & & & & & & & & & & & & \\
\hline Legal adviser & & & & & & & & • & & & & & & & & & & \\
\hline Logistic provider & & & & & & & & - & & & & & & & & & & \\
\hline Freight forwarder & & & & & & & & - & & & & & & & & & & \\
\hline $\begin{array}{l}\text { Universities / Research } \\
\text { institutes }\end{array}$ & & & & & • & & $\bullet$ & & & & & & & & & & & \\
\hline Design partner & & & & & & & • & & & & & & & & & & & \\
\hline Technological partner & & & & & & & - & & & & & & & & & & & \\
\hline $\begin{array}{l}\text { Payment } \\
\text { provider }\end{array}$ & & & & & & & & & & • & & & & & & & & \\
\hline App developer & & & & & & & & & & & & $\bullet$ & & & & & & \\
\hline Retailer & & & & & & & & & & & & & & & & & & • \\
\hline Recycling company & & & & & & & & & & & & & & & & & & - \\
\hline $\begin{array}{l}\text { A. (Överholm, 2017) } \\
\text { B. (Benedetti } \text { et al., 2016) } \\
\text { C. (Ferreira } \text { et al., 2016) } \\
\text { D. (Gilles and Christine, } 20 \\
\text { E. (Hannon, Foxon and Gal } \\
\text { F. (Hollauer, Venkataramar } \\
\text { Omer, 2015) } \\
\text { G. (Lucile, Alan and Danie } \\
\text { H. (Peruzzini, Marilungo ar } \\
\text { Germani, 2015) }\end{array}$ & $\begin{array}{l}\text { 16) } \\
\text { le, } 2 \\
n \text { an }\end{array}$ & $\begin{array}{l}015) \\
d \\
015)\end{array}$ & & $\begin{array}{l}\text { I. ( } \\
\text { a } \\
\text { J } \\
\text { K. } \\
\text { L. } \\
\text { M. } \\
\text { N. }\end{array}$ & $\begin{array}{l}\text { (Rivas } \\
\text { and S } \\
\text { J. (Zh } \\
\text { (Ziou } \\
\text {. (Zol } \\
\text { Böl } \\
\text { (Yip, } \\
\text { (Pan, }\end{array}$ & $\begin{array}{l}\text { s-He } \\
\text { Schee } \\
\text { hang } \\
\text { ut an } \\
\text { lnow } \\
\text { hma } \\
\text { Pha } \\
2 \\
\text { larot }\end{array}$ & $\begin{array}{l}\text { erma } \\
\text { epen } \\
\text { et a } \\
\text { nd A } \\
\text { vski, } \\
\text { ann, } \\
\text { aal a } \\
\text { 2013) } \\
\text { tto et }\end{array}$ & $\begin{array}{l}\text { nn, K } \\
\text { s, } 201 \\
\text { l., } 20 \\
\text { zab, } 2 \\
\text { Weiß } \\
\text { 2014) } \\
\text { ind Pr } \\
\text { al., } 2\end{array}$ & $\begin{array}{l}\text { Köhler } \\
15) \\
15) \\
2015) \\
\beta \text { and } \\
\text { ) } \\
\text { robert, } \\
2013)\end{array}$ & & $\begin{array}{l}\text { O. } \\
\text { Q. } \\
\text { R. }\end{array}$ & $\begin{array}{l}(\mathrm{Va} \\
\mathrm{F} \\
(\mathrm{Z} \\
\text { (B) } \\
\mathrm{S} .\end{array}$ & $\begin{array}{l}\text { sant } \\
\text { P. }(\mathrm{K} \\
\text { tong } \\
\text { erge } \\
\text { (Tan } \\
\text { T. () }\end{array}$ & $\begin{array}{l}\mathrm{ma} \\
\mathrm{W}, \mathrm{M} \\
\text { Will }\end{array}$ & $\begin{array}{r}\text { et al } \\
\text { et a } \\
\text { Dan } \\
\text { Jia } \\
\text { et a } \\
\text { Icalo } \\
\text { Ga } \\
\text { liam }\end{array}$ & $\begin{array}{l}., 2 \\
l ., 2 \\
\text { l. } 2,2 \\
l ., 2 \\
\text { lan } \\
\text { lisene } \\
11,2\end{array}$ & $\begin{array}{l}013) \\
2012 \\
n \text { and } \\
2012 \\
2011 \\
\text { e and } \\
2007 \\
2006\end{array}$ & \\
\hline
\end{tabular}

Regarding the customer group, some authors use the term "consumer" to refer to this one with a similar connotation, but it is not clear what is the difference between them. Another stakeholder widely cited is users. They interact with the product or service and can have a specific role in the PSS design (with a different meaning in relation to "customer" or "consumer"). 
Other stakeholders widely cited in the cases are the financial partner (highlighting the relevance of investors or groups dealing with business case), government, and local providers (as integrators in the PSS). Society and provider for checkout and terminals (which ensure the PSS' operation) are also significant stakeholders, being followed by the insurer, and particular industry interest group, authority and domain experts. Those stakeholders represent groups to be engaged in a more active way in the PSS design and they should be recognized as co-participants in the PSS design. In a business system domain, the relationship among different stakeholders sustains the value network. This points out the importance of involving non-customer stakeholders during the co-creation of PSS value propositions.

In general, based on the list presented in Table 2, the stakeholders can be structured into four spheres: customer sphere (e.g., customer/consumer, user); provision sphere (e.g., manufacturer, installation and service partner, supplier, local provide); partners of the PSS provider's value network (e.g., financial partner, design partner, technological partner, recycling companies); and environmental sphere (e.g., competitors, industry interest groups, insurer, universities and research institutes, etc.).

Among the stakeholders, 13 of them are presented in unique cases, e.g. entertainment firm, freight forward and app developer. They may be involved in a particular situation in the PSS design. This does not mean that they are not important. On the contrary, their roles are contingent on the company's position at a particular time, i.e., less-immediate stakeholders may present greater concern than others.

Two stakeholders are highlighted: legal adviser and recycling company. The first one is experts leading with legal issues regarding the service level agreement (SLA) contracts in the PSS, which is a deal upon the provider's proposal, agreed with the customer, that concerns the service specifications agreement and cost negotiation as part of the service taxation and invoicing of the PSS contracted (Borangiu et al., 2014). They should be widely contemplated, especially in the most critical cases of PSS provision, and when the PSS is result-oriented because the "client and provider in principle agree on a result" (Tukker, 2004). The recycling company is a stakeholder that operates in the end-of-life of a PSS. Although some authors discuss the contribution of the PSS to the development of a sustainable and circular economy (Tukker, 2015), stakeholders that act in the final stages of the PSS lifecycle have not been well-approached since the early stages of the design process.

The PSS literature mainly describes external stakeholders, e.g., supplier, government, society, and competitors. The involvement and understanding of the internal actors (e.g., employees, shareholders, etc.) of the system must be also contemplated. Gilles and Christine (2016) and Tan, Mcaloone and Gall (2007) focused on identifying the company's internal stakeholders. By doing that, the business culture perspective is considered on the PSS design besides the attention to the market orientation.

\subsection{Terminology for stakeholders in PSS literature}

A broad set of different terminology is applied in the studies to refer to the stakeholders of a PSS.

The most used term as a synonym of stakeholder is "partner(s)" (e.g., Williams, 2006; Tan, Mcaloone and Gall, 2007; Bergema et al., 2011; Kim et al., 2012; Panarotto et al., 2013). Usually, in those studies, the stakeholder is considered in the domain of partnerships with the provider. However, other studies consider "partner" as a kind of stakeholder, as can be seen in Table 2 (e.g., design partner).

"Actor(s)" is the second most used term, as observed in Rivas-Hermann, Köhler and Scheepens (2015); Ferreira et al. (2016), and Överholm (2017), for example. They are related to the supply and demand aspects of the PSS, whose perspective may influence the relations during the solutions' provision. In this context, the term "actor" alludes to individuals or groups that act in the design and do not have only concerns involved in it. Another term used is "player" (e.g., Hannon, Foxon and Gale, 2015). This term alludes to individuals or groups that take part in an activity and have a high influence in the design process. Some authors also use the "network" designation (e.g., Gilles and Christine, 2016) and their derivation for referring to stakeholders, such as "network of players", "network of actors", "alliance network", "network of contributors", "supply network", and "network environment". Traditionally, the term "network" designates to individuals or groups connected in a system within and between businesses. In this sense, the network represents the connection between different stakeholders.

The stakeholder's designation can be found by means of multiple terms, and the same authors use different terminologies for referring to the stakeholders in the context of the PSS. Therefore, the literature is not homogeneous regarding the designations of "stakeholders". Different terminologies can impact in a misunderstanding of the concept of "stakeholders" which makes difficult the companies to identify the individuals or groups to be involved in the PSS design. The terminology is considered the foundation basis for this activity during the PSS design. 


\section{FINAL CONSIDERATIONS}

\subsection{Contributions}

This study provides a list of stakeholders that can be considered by companies in the servitization and PSS design process. Up to now, there is no study that consolidates who could be the stakeholders in the context of PSS design. The identification of the stakeholders is one of the main steps when designing the PSS value proposition. Using this list as a reference, researchers and companies can become aware of the individuals or groups to be involved in the early stages of the design process. The stakeholders, mainly those who are considered as less-immediate, will be not neglected. This allows that the concerns and demands of all stakeholders will be taken into consideration.

The knowledge about the main stakeholders of a PSS favors the business model design. Based on the definitions in the literature, the PSS core concept is to provide an integrated solution of products and services for generating value added for customers. Customers then acquire the benefits related to the PSS offering. However, for the value to be satisfactorily delivered to customers, the PSS must be provided precisely. For this, it is needed the engagement of several stakeholders. This fact highlights the importance of a long-term relationship between stakeholders outside their traditional sphere of influence to move towards the systemic changes needed for the PSS design and implementation.

In a system where the product offerings are integrated with service offerings, the number of different stakeholders that could be involved in the PSS design and its operation increases considerably, especially in cases where the PSS is result-oriented.

In PSS business environment, different stakeholders, who have different disciplinary backgrounds, needs, and intentions, must be considered and engaged since the PSS beginning of life, i.e. even the stakeholders that act in the operation and disposal of a PSS should be involved in the early stages of the PSS design. Stakeholder' interests and concerns, and their consequent requirements may vary depending on the PSS life-cycle stage, as well as of the value created and delivered. This may increase the maturity of the solutions and the value offered through the solution for all stakeholders, reducing the managerial and technical risks, as well as ensuring economic advantages.

\subsection{Limitations and future researches}

Limitations of this study are related to the strategy employed for listing the stakeholders. There are few case studies indicating who are the stakeholders that could be engaged in the PSS design. This may be a consequence of few empirical studies. This indicates the need for leveraging research design, seeking a balance between conceptual research and application of the theory. Further research should identify the stakeholders by employing different strategies, such as interviews with companies.

Another limitation refers to the analysis of the terms used as equivalent to the term "stakeholder". Multiple terminologies are used to refer to stakeholders. The deeper understanding of the different terms can expand the scope of the searches. Next steps of this research aim looking for other stakeholders in PSS's case studies using the different terms for "stakeholders". From this, it is intended to define a value proposition method considering the different stakeholders in accordance with the type of PSS and its life cycle stage.

\section{REFERENCES}

Annarelli, A., Battistella, C. and Nonino, F. (2016), "Product service system: A conceptual framework from a systematic review", Journal of Cleaner Production. Elsevier Ltd, Vol. 139, pp. 1011-1032. https://dx.doi/org/10.1016/j.jclepro.2016.08.061.

Baines, T., Lightfoot, H. W., Benedettini, O. and Kay, J.M. (2009), "The servitization of manufacturing: a review of literature and reflection on future challenges", Journal of Manufacturing Technology Management, Vol. 20 No.5, pp. 547-567. https://dx.doi/org/10.1108/17410380910960984.

Baines, T. S., Lightfoot, H., Steve, E., Neely, A., Greenough, R., Peppard, J., Roy, R., Shehab, E., Braganza, A., Tiwari, A., Alcock, J., Angus, J., Bastl, M., Cousens, A., Irving, P., Johnson, M., Kingston, J., Lockett, H., Martinez, V., Michele, P., Tranfield, D., Walton, I. and Wilson, H. (2007), "State-of-the-art in product-service systems", Journal of Engineering Manufacture, Vol. 221 No.10, pp. 1543-1552. https://dx.doi/org/10.1243/ $09544054 J E M 858$.

Baines, T. S., Bigdeli, A. Z., Bustinza, O. F., Shi, V. G., Baldwin, J. and Ridgway, K. (2017), "Servitization: Revisiting the state-of-the-art and research priorities", International Journal of Operations \& Production Management, Vol. 37 No.2, pp. 256-278. https://dx.doi/org/10.1108/IJOPM-06-2015-0312. 
Benedetti, M., Rondini, A., Introna, V., Cesarotti, V. and Cavalieri, S. (2016), "Service engineering methodology and energy services: applicability analysis and case study”, In: Procedia CIRP. Elsevier B.V., pp. 358-363. https://dx.doi/org/10.1016/j.procir.2016.03.072.

Bergema, K., Kleinsmann, M., Bont, C. and Valkenburg, R. (2011), "Exploring collaboration in a networked innovation project in industry", In: ICED 11 - 18th International Conference on Engineering Design Impacting Society Through Engineering Design. Denmark, pp. 211-220.

Bertoni, A., Bertoni, M., Panarotto, M. and Johansson, C. (2016), "Value-driven product service systems development: Methods and industrial applications", CIRP Journal of Manufacturing Science and Technology. CIRP, Vol. 15, pp. 42-55. https://dx.doi/org/10.1016/j.cirpj.2016.04.008.

Beuren, F. H., Ferreira, M. G. G. and Miguel, P. A. C. (2013), "Product-service systems: A literature review on integrated products and services", Journal of Cleaner Production. Elsevier Ltd, Vol. 47, pp. 222-231. https://dx.doi/org/10.1016/j.jclepro.2012.12.028.

Boehm, M. and Thomas, O. (2013), "Looking beyond the rim of one's teacup: A multidisciplinary literature review of product-service systems in information systems, business management, and engineering \& design", Journal of Cleaner Production. Elsevier Ltd, Vol. 51, pp. 245-260. https://dx.doi/org/10.1016/j.jclepro.2013.01.019.

Borangiu, T., Dragoicea, M., Oltean, V. E. and Iacob, I. (2014), "Service orientation in holonic and multi-agent manufacturing”, In: Studies in Computational Intelligence. Springer, pp. 159-175. https://dx.doi/org/10.1007/ 978-3-319-30337-6.

Cavalieri, S. and Pezzotta, G. (2012), "Product-service systems engineering: State of the art and research challenges", Computers in Industry. Elsevier B.V., Vol. 63 No.4, pp. 278-288. https://dx.doi/org/10.1016/j.compind.2012.02.006.

Elo, S. and Kyngäs, H. (2008), “The qualitative content analysis process”, Journal of Advanced Nursing, Vol. 62 No.1, pp. 107-115. https://dx.doi/org/10.1111/j.1365-2648.2007.04569.x.

Evans, S., Partidário, P. J. and Lambert, J. (2007), "Industrialization as a key element of sustainable product-service solutions", International Journal of Production Research, Vol. 45 No. 18-19, pp. 4225-4246. https://dx.doi/org/10.1080/00207540701449999.

Ferreira, F. N. H., Cova, B., Spencer, R. and Proença, J. F. (2016), “A dynamics-based approach to solutions typology: A case from the aerospace industry”, Industrial Marketing Management. Elsevier Inc., Vol. 58, pp. 114-122. https://dx.doi/org/10.1016/j.indmarman.2016.05.025.

Frow, P. and Payne, A. (2011), “A stakeholder perspective of the value proposition concept”, European Journal of Marketing, Vol. 45 No.1/2, pp. 223-240. https://dx.doi/org/10.1108/03090561111095676.

Gilles, N. and Christine, L. C. (2016), "The sustainable value proposition of PSSs: The case of ECOBEL 'shower Head'”, Procedia CIRP. Elsevier B.V., Vol. 47, pp. 12-17. https://dx.doi/org/10.1016/j.procir.2016.03.043.

Hannon, M. J., Foxon, T. J. and Gale, W. F. (2015), "Demand pull” government policies to support product-service system activity: The case of energy service companies (ESCos) in the UK”, Journal of Cleaner Production. Elsevier Ltd, Vol. 108, pp. 1-16. https://dx.doi/org/10.1016/j.jclepro.2015.05.082.

Hollauer, C., Venkataraman, S. and Omer, M. (2015), "A model to describe use phase of socio-technical sphere of Product-Service Systems", In 20th International Conference on Engineering Design, pp. 1-10.

Kim, Y. S., Lee, S. W., Lee, J., Han, D. M. and Lee, H. K. (2011), "Design support tools for product-servce systems”, International Conference on Engineering Design (ICED11), Vol. 1 No. August, pp. 288-298.

Kim, Y. S., Lee, S. W., Kim, J. H. and Do, S. H. (2012), “A design case of product-service systems - Urban umbrella rental PSS", Proceedings of International Design Conference, DESIGN, Vol. DS 70, pp. 213-222.

Krucken, L. and Meroni, A. (2006), "Building stakeholder networks to develop and deliver product-service-systems: practical experiences on elaborating pro-active materials for communication", Journal of Cleaner Production, Vol. 14 No.17, pp. 1502-1508. https://dx.doi/org/10.1016/j.jclepro.2006.01.026.

Laurischkat, K. and Viertelhausen, A. (2017), "Business model gaming: A game-based methodology for E-Mobility business model innovation", Procedia CIRP. The Author(s), Vol. 64, pp. 115-120. https://dx.doi/org/10.1016/j.procir.2017.03.051.

Levy, Y. and Ellis, T. J. (2006), “A systems approach to conduct an effective literature review in support of information systems research”, Informing Science Journal, Vol. 9, pp. 181-212.

Lucile, T., Alan, L. and Daniel, B. (2015), "New PSS design method of a pneumatic energy system", Procedia CIRP. Elsevier B.V., Vol. 30, pp. 48-53. https://dx.doi/org/10.1016/j.procir.2015.02.034.

Medini, K. and Boucher, X. (2016), "Configuration of product-service systems value networks - Evidence from an innovative sector for sludge treatment”, CIRP Journal of Manufacturing Science and Technology. CIRP, Vol. 12, pp. 14-24. https://dx.doi/org/10.1016/j.cirpj.2015.10.003.

Morioka, S. N., Evans, S. and De Carvalho, M. M. (2016), "Sustainable Business Model Innovation: Exploring Evidences in Sustainability Reporting”, Procedia CIRP. Elsevier B.V., Vol. 40, pp. 660-668. https://dx.doi/org/10.1016/j.procir.2016.01.151.

Överholm, H. (2017), "Alliance formation by intermediary ventures in the solar service industry: implications for product-service systems research", Journal of Cleaner Production, Vol. 140, pp. 288-298. https://dx.doi/org/10.1016/j.jclepro.2015.07.061. 
Panarotto, M., Larsson, T. and Larsson, A. (2013), "Enhancing supply chain collaboration in automotive industry by value driven simulation", Proceedings of the International Conference on Engineering Design, ICED, Vol. 4 DS75-04 No. August, pp. 447-456. Available at: http://www.scopus.com/inward/record. url?eid=2-s2.0-84897590863\&partnerID=40\&md5=f9007d1454b82db9a97eaa9f313c7496.

Panarotto, M., Wall, J. and Larsson, T. (2017), "Simulation-driven design for assessing strategic decisions in the conceptual design of circular PSS business models", Procedia CIRP, Vol. 64, pp. 25-30. https://dx.doi/org/10.1016/j.procir.2017.03.026.

Park, Y., Geum, Y. and Lee, H. (2012), "Toward integration of products and services: Taxonomy and typology", Journal of Engineering and Technology Management - JET-M. Elsevier B.V., Vol. 29 No.4, pp. 528-545. https://dx.doi/org/10.1016/j.jengtecman.2012.08.002.

Peruzzini, M., Marilungo, E. and Germani, M. (2015), “Technical-business design methodology for PSS”, In: Al, R. C. et (ed.) Advances in Transdisciplinary Engineering, pp. 513-522. https://dx.doi/org/10.3233/978-1-61499544-9-513.

Rabetino, R., Harmsen, W., Kohtamaki, M. and Sihvonen, J. (2018), "Structuring servitization-related research", International Journal of Operations \& Production Management, Vol. 38 No.2, pp. 350-371. https://dx.doi/org/10.1108/IJOPM-03-2017-0175.

Rivas-Hermann, R., Köhler, J. and Scheepens, A. E. (2015), "Innovation in product and services in the shipping retrofit industry: A case study of ballast water treatment systems", Journal of Cleaner Production, Vol. 106 No. April 2014, pp. 443-454. https://dx.doi/org/10.1016/j.jclepro.2014.06.062.

Rozenfeld, H., Rosa, M. and Fernandes, S. C. (2018), "Servitization methodology: PSS design, change management or business model innovation?”, In: Schützer, K. (ed.) Proceedings of the 23rd International Seminar on High Technology. UNIMEP, Piracicaba, pp. 91-116.

Tan, A. R., Mcaloone, T. C. and Gall, C. (2007), "Product / service-system development - an explorative case study in a manufacturing company", International Conference Design, No. August, p. 12.

Tukker, A. (2004), "Eight types of product-service systems", Business Strategy and the Environment, Vol. 13, pp. 246-260. https://dx.doi/org/10.1002/bse.414.

Tukker, A. (2015), "Product services for a resource-efficient and circular economy - A review", Journal of Cleaner Production. Elsevier Ltd, Vol. 97, pp. 76-91. https://dx.doi/org/10.1016/j.jclepro.2013.11.049.

Vasantha, G.A., Hussain, R., Cakkol, M. and Roy, R. (2013), "Product-Service Systems Design Using Stakeholders' Information”, In: CIRP Design. Springer-Verlag, London, pp. 353-366. https://dx.doi/org/10.1007/978-1-44714507-3.

Velamuri, V. K., Neyer, A. K. and Möslein, K. M. (2011), "Hybrid value creation: A systematic review of an evolving research area”, Journal fur Betriebswirtschaft, Vol. 61 No. 1, pp. 3-35. https://dx.doi/org/10.1007/s11301-0110070-5.

Webster, J. and Watson, R. T. (2002), "Analyzing the past to prepare for the future: writing a literature review”, MIS Quarterly, Vol. 26 No. 2.

Williams, A. (2006), "Product-service systems in the automotive industry: The case of micro-factory retailing", Journal of Cleaner Production, Vol. 14 No. 2, pp. 172-184. https://dx.doi/org/10.1016/j.jclepro.2004.09.003.

Yip, M. H., Phaal, R. and Probert, D. R. (2013), "Stakeholder Engagement in Early Stage Product-Service System Development for Healthcare Informatics”, In: 2013 Proceedings of Technology Management in the IT-Driven Services, pp. 2564-2574.

Zhang, L., Zhang, J., Duan, Z. and Bryde, D. (2015), "Sustainable bike-sharing systems: Characteristics and commonalities across cases in urban China", Journal of Cleaner Production. Elsevier Ltd, Vol. 97, pp. 124-133. https://dx.doi/org/10.1016/j.jclepro.2014.04.006.

Ziout, A. and Azab, A. (2015), "Industrial product service system: A case study from the agriculture sector", Procedia CIRP. Elsevier B.V., Vol. 33, pp. 64-69. https://dx.doi/org/10.1016/j.procir.2015.06.013.

Zolnowski, A., Weiß, C. and Böhmann, T. (2014), "Representing service business models with the service business model canvas - The case of a mobile payment service in the retail industry", Proceedings of the Annual Hawaii International Conference on System Sciences, pp. 718-727. https://dx.doi/org/10.1109/HICSS.2014.96.

Zonghu, L., Dandan, S. and Jian, S. (2012), "Research on profit model of diesel engine products-services system", Advanced Materials Research, Vol. 544, pp. 82-87.

https://dx.doi/org/10.4028/www.scientific.net/AMR.544.82.

\section{ACKNOWLEDGMENTS}

This study was supported by São Paulo Research Foundation (FAPESP) under the processes 2017/27144-3 and 2018/13024-9. The opinions, hypotheses and conclusions or recommendations expressed in this material are of responsibility of the authors and do not necessarily reflect the views of FAPESP. The authors would like to extend sincere thanks to São Paulo Research Foundation (FAPESP), Brazilian Council for Scientific and Technological Development (CNPq) and the Higher Education Personnel Improvement Coordination (Capes) for supporting this research. 